\title{
Scenarios of Twenty-First Century Mean Sea Level Rise at Tide-Gauge Stations Across Canada
}

\author{
Guoqi Han ${ }^{1,2, *}$, Zhimin $\mathrm{Ma}^{2}$, and Aimée B.A. Slangen ${ }^{3}$ \\ ${ }^{1}$ Institute of Ocean Sciences, Fisheries and Oceans Canada, Sidney, British Columbia, Canada \\ ${ }^{2}$ Northwest Atlantic Fisheries Centre, Fisheries and Oceans Canada, St. John's, Newfoundland and \\ Labrador, Canada \\ ${ }^{3}$ Royal Netherlands Institute for Sea Research (NIOZ), Department of Estuarine and Delta Systems, \\ Utrecht University, Yerseke, The Netherlands
}

[Original manuscript received 7 June 2018; accepted 2 June 2020]

\begin{abstract}
Existing scientific literature and international assessments, such as those by the Intergovernmental Panel on Climate Change, provide a wide range of projections for global mean sea level rise (SLR) in the twenty-first century. At the local scale, the ranges or uncertainties of projections are even larger. There is a pressing need to compile plausible local SLR scenarios to aid coastal communities with adaptation. Here we develop three local SLR scenarios for Canadian tide-gauge stations for the twenty-first century (Low, Intermediate, and High). Our Low Scenario is based on projections under the Representative Concentration Pathway 4.5 (RCP4.5) scaled down to the present global SLR rate. Our Intermediate Scenario is based on projections under the Representative Concentration Pathway 8.5 (RCP8.5), and our High Scenario is based on the RCP8.5 projections with an adjusted contribution from the Antarctic ice sheet. For all three scenarios, we use vertical land motion (VLM) from global positioning systems (GPS) data corrected for the present-day melt of glaciers and ice sheets instead of the commonly used VLM from a glacial isostatic adjustment (GIA) model. The GPS data include not only GIA but also other processes affecting VLM. For each scenario, larger SLR is projected along the southeastern Atlantic coast, the Pacific coast, and the Beaufort Sea coast than along other Canadian coasts in the twentyfirst century. Under the Low, Intermediate, and High Scenarios, the median relative sea level along the southeastern Atlantic coast may rise by as much as 0.35, 0.82, and $0.96 \mathrm{~m}$, respectively, over 2010-2100. The proposed scenarios allow coastal engineers and managers to consider multiple future conditions and develop multiple response options, as well as choose the most suitable option according to the risk tolerance of infrastructure.
\end{abstract}

RÉSUMÉ [Traduit par la rédaction] Les articles scientifiques et les évaluations internationales actuels, comme celles du Groupe d'experts intergouvernemental sur l'évolution du climat, proposent un large éventail de projections concernant la hausse du niveau mondial moyen de la mer au XXI siècle. À l'échelle locale, les écarts entre les projections, ou leur incertitude, s'avèrent encore plus grands. Il faut instamment compiler des scénarios locaux plausibles de hausse afin de permettre aux communautés côtières de s'adapter. Nous définissons ici trois scénarios de hausse locale (faible, modérée et élevée) pour les stations marégraphiques canadiennes au XXI siècle. Le scénario d'une faible hausse se fonde sur les projections selon le profil représentatif d'évolution de concentration 4.5 (RCP4.5), mis à l'échelle suivant le taux actuel de hausse mondiale. Le scénario de hausse modérée se fonde sur les projections selon le profil représentatif d'évolution de concentration 8.5 (RCP8.5) et le scénario de hausse élevée se fonde aussi sur les projections selon le RCP8.5, mais comprend la contribution ajustée de la nappe glaciaire de l'Antarctique. Pour les trois scénarios, nous utilisons le mouvement terrestre vertical provenant des données du système de positionnement mondial (GPS), corrigées pour la fonte actuelle des glaciers et des nappes glaciaires, au lieu du mouvement vertical couramment utilisé provenant d'un modèle d'ajustement isostatique des glaciers. Les données GPS comprennent non seulement l'ajustement isostatique, mais aussi d'autres processus régissant le mouvement terrestre. Pour chaque scénario, nous prévoyons une hausse du niveau de la mer plus importante le long de la côte sud-est de l'Atlantique, de la côte du Pacifique et de la côte de la mer de Beaufort que le long des autres côtes canadiennes, au XXI siècle. Pour les scénarios de hausses faible, modérée et élevée, les niveaux relatifs médians de la mer le long de la côte sud-est de l'Atlantique pourraient s'élever à $0,35 \mathrm{~m}$, $0,82 \mathrm{~m}$ et 0,96 m, respectivement, entre 2010 et 2100. Les scénarios proposés permettent aux ingénieurs et aux gestionnaires que préoccupe le littoral de prendre en compte diverses conditions futures et de préparer les mesures d'intervention correspondantes, ainsi que de choisir l'option qui convient le mieux en fonction de la tolérance au risque des infrastructures.

*Corresponding author's email: Guoqi.Han@dfo-mpo.gc.ca 


\section{8 / Guoqi Han et al.}

KEYWORDS sea level rise; scenarios; local sea level projections; vertical land motion; global positioning systems data

\section{Introduction}

To date, extensive efforts have been made to develop processbased sea level projections at global and regional scales (e.g., Church et al., 2013). Converting projections at these scales to local sea level projections remains a subject of much discussion. In the present paper we make local sea level projections for Canada with three scenarios. We merge conventional process-based sea level projections with observationally based vertical land motion (VLM) where such a merger requires attribution of VLM into its components to prevent double counting.

The Intergovernmental Panel on Climate Change (IPCC) Fifth Assessment Report (AR5) provided a wide range of projections for global mean sea level rise (SLR) in the twenty-first century. For example, the process-based projections from the IPCC AR5 (Church et al., 2013) have 5th to 95th percentile ranges of $0.32-0.63 \mathrm{~m}$ and $0.45-0.82 \mathrm{~m}$ from $1986-2005$ to 2081-2100 under the Representative Concentration Pathway 4.5 (RCP4.5) (a medium emission scenario) and RCP8.5 (a high emission scenario) (Moss et al., 2010), respectively. Subsequently, the process-based work of Slangen et al. (2014) found a global mean SLR of $0.54 \pm 0.19 \mathrm{~m}$ (mean \pm one standard deviation) and $0.71 \pm 0.28 \mathrm{~m}$ from 1986-2005 to 20812100 under RCP4.5 and RCP8.5, respectively. Slangen et al. (2014) also showed that regional mean SLR varies from $50 \%$ below the global mean to $30 \%$ above in the twentyfirst century. Kopp et al. (2014) provided probabilistic global SLR ranges of $0.4-0.9 \mathrm{~m}$ (5th-95th percentiles) and 0.5-1.2 m from 2000 to 2100 under RCP4.5 and RCP8.5, respectively. Jackson and Jevrejeva's (2016) process-based probabilistic projection obtained an SLR of $0.37-1.18 \mathrm{~m}$ (5th-95th percentiles) by 2100 under RCP8.5. Kopp et al. (2017) incorporated the Antarctic ice-sheet physics of DeConto and Pollard (2016) into probabilistic sea-level projections and obtained a twenty-first century SLR of 0.9$2.4 \mathrm{~m}$ (5th-95th percentiles) under RCP8.5. Semi-empirical projections under RCP4.5 have 5th-95th percentile ranges of $0.43-0.69 \mathrm{~m}$ (Jevrejeva et al., 2012) to $0.82-1.12 \mathrm{~m}$ (Rahmstorf et al., 2012) for the same period. Kopp et al. (2017) and Mengel et al. (2016) made significant efforts to align semiempirical global sea level projections with process-based ones in IPCC AR5. In addition to these approaches to making sea level projections, others include possibilistic methods (Le Cozannet et al., 2017) and physically based emulators (e.g., Palmer et al., 2018). For general reviews on methods of sea-level projections and impacts, refer to Garner et al. (2018) and van der Pol and Hinkel (2019).

For sea level projections around Canada, Mazzotti et al. (2008) and Thomson et al. (2008) showed that sea level changes along the Canadian western coast will be highly variable over the twenty-first century $(0.05-0.5 \mathrm{~m})$. James et al. (2014) provided sea level projections for coastal locations across Canada and the adjacent United States by utilizing the IPCC AR5 regional sea level projections (Church et al., 2013) and GPS-measured VLM. Projected local SLR (relative to land) over the twenty-first century varies spatially from almost zero to $0.7 \mathrm{~m}$ along the eastern coast of Canada (Han et al., 2014). Similar findings were made by $\mathrm{Han}$ et al. (2015) who estimated median sea level projections at selected tide-gauge stations across Canada from 1986-2005 to 20802099, using the RCP4.5 and RCP8.5 scenarios, ranging from $-0.75 \mathrm{~m}$ in the eastern Arctic to $0.70 \mathrm{~m}$ in the southeastern Atlantic. They adjusted the regional sea level projections at these sites from Slangen et al. (2014) by accounting for VLM measured by global positioning systems (GPS). The sea level projections of Han et al. (2015) have a similar pattern to those of James et al. (2014). However, Han et al. (2015) did not correct for (i.e., remove) the effect of present land-ice melt on VLM. This effect is small (a few centimetres over a century) along the Canadian Atlantic and Pacific Coasts and can be up to $0.2 \mathrm{~m}$ at tide-gauge locations in the Canadian High Arctic (James et al., 2014) though no information on the calculation of this effect is available (James et al., 2014).

Clearly, existing scientific literature and international assessments produce a wide range of estimates for future global mean SLR. At the local scale, the ranges and uncertainties are even larger. It has been found that the increasing mean SLR has increased the frequency, magnitude, and duration of coastal flooding around many coastlines worldwide (Aarup et al., 2010; Wahl et al., 2017). Higher mean sea levels increase the impact of storm surges, wind-waves, and high tides and, therefore, the potential severity of coastal flooding (Muis et al., 2017). At present, coastal engineers and managers are left to determine SLR estimates through their own interpretation of the scientific literature or the advice of experts on an ad hoc basis. Given the large uncertainties in SLR projections in the scientific literature, it is important to develop scenarios that describe future potential sea level conditions in a manner that supports decision-making under uncertain conditions (van der Pol \& Hinkel, 2019). In recognition of the importance of agreed-upon SLR scenarios, the National Oceanic and Atmospheric Administration (NOAA) established four scenarios for global mean SLR for the 1992-2100 period: Highest $(2.0 \mathrm{~m})$, Intermediate-High $(1.2 \mathrm{~m})$, Intermediate-Low $(0.5 \mathrm{~m})$, and Lowest $(0.2 \mathrm{~m})$ (Parris et al., 2012). These scenarios have been updated by Sweet et al. (2017) and expanded to six SLR scenarios ranging from 0.3 to $2.5 \mathrm{~m}$. However, determination of the global mean SLR scenarios is merely the very first step. What coastal engineers and managers need are SLR scenarios at local or regional scales. In a recent paper, Hinkel et al. (2015) suggested considering upper and lower bound scenarios depending on risk tolerance. They also suggested that coastal planners should adjust infrastructure in the shorter 


\section{Scenarios of Twenty-First Century Mean Sea Level Rise across Canada / 289}

term but keep the option open for adjustment a few decades from now as new information becomes available, as done in the Thames Estuary 2100 project (Ranger et al., 2013).

In this study, we develop three local SLR scenarios (Low, Intermediate, and High) at selected tide-gauge sites in Canada by combining local information and regionalized global sea level scenarios. The Low Scenario uses the regional sea level projections under RCP4.5 of Slangen et al. (2014), assumes the continuation of the present rate of global mean sea level rise (SLR) through 2100, and corrects for VLM estimated by GPS. The Intermediate Scenario draws from the regional sea level projections under RCP8.5 from Slangen et al. (2014) corrected for VLM estimated by GPS. The High Scenario is an adjustment to the Intermediate Scenario with an additional contribution from the melting Antarctic ice sheet based on the latest research of Edwards et al. (2019). The effect of the present-day land-ice melt on VLM is removed from the GPS VLM in this study to improve the projections first made by Han et al. (2014, 2015). Our objective is to provide updated local SLR scenarios at selected tide-gauge stations along the Canadian coast (Atlantic, Pacific, and Arctic) that can support coastal engineers and managers in the design and maintenance of coastal infrastructure under a changing climate.

\section{Data and Method}

a Construction of Local Sea-Level Change Scenarios We define three SLR scenarios: Low, Intermediate, and High for selected tide-gauge stations in Canada (see Fig. 1 and

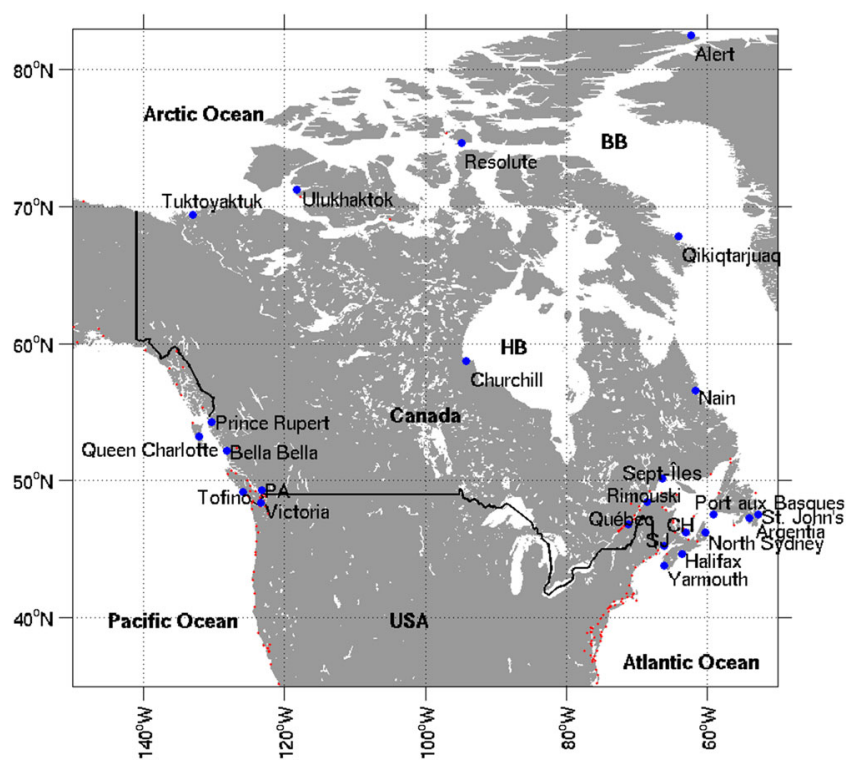

Fig. 1 Map of the study region and the location of selected tide-gauge stations (blue dots) and unselected tidal gauge stations (small red dots) around Canada and the United States in the Permanent Service for Mean Sea Level (PSMSL) database. BB: Baffin Bay; $\mathrm{CH}$ : Charlottetown; HB: Hudson Bay; PA: Point Atkinson; and SJ: Saint John.
Table 1 for their locations). We use regional sea level projections under the RCP4.5 and RCP8.5 scenarios (Slangen et al., 2014) from 1986-2005 to 2081-2100, which are based on an ensemble mean of 21 climate models (see the Online Resource Table 1 in Slangen et al.). There are no projections available directly in Hudson Bay or the Canadian Arctic Archipelago (CAA) because a subset of the 21 climate models do not resolve these regions. Therefore, we select a grid point nearest the tide-gauge site for the projections. For Churchill, we select the nearest available grid point on the Atlantic side $\left(63.5^{\circ} \mathrm{W}, 59.5^{\circ} \mathrm{N}\right)$. From the sea surface height output of the Simple Ocean Data Assimilation model (Carton \& Giese, 2008), the sea level rates over 1980-2018 and their $90 \%$ confidence levels are $2.1 \pm 0.7$ at Churchill and $1.1 \pm 1.0 \mathrm{~mm} \mathrm{yr}^{-1}$ at the nearest Atlantic coast grid point. The rates, though notably different in values, indicate rising trends at both stations and their uncertainties overlap at the $95 \%$ confidence level. The correlation coefficient of the annual sea level anomalies at the two locations is 0.72 over $1980-2018$, significant at the $99 \%$ confidence level. The local SLR projections at tide-gauge stations account for (i) the steric and dynamic ocean effects obtained from the ensemble mean of global climate models (Slangen et al., 2014); (ii) the model-based land-ice melt effects (Slangen et al., 2014); (iii) the modelbased groundwater depletion effects (Slangen et al., 2014), and (iv) the glacial isostatic adjustment (GIA) effect from Stuhne and Peltier's (2015) ICE-6G_C model.

The GIA causes land subsidence (uplift) in the vertical, which increases (decreases) relative sea level (RSL) (Mitrovica et al., 2001; Peltier, 2004). Simultaneously, the GIA causes a decrease (increase) in gravitational attraction that decreases (increases) sea surface topography and thus RSL. In Canada, the effect of land subsidence or uplift due to GIA is dominant over that of gravitational attraction in the sea level signal. The GIA model (ICE-6G, VM2) of Stuhne and Peltier (2015) provides rates (millimetres per year) for VLM $\left(\mathrm{VLM}_{\mathrm{GIA}}\right)$ and net RSL change $\left(\mathrm{RSL}_{\mathrm{GIA}}\right.$, including both the VLM and gravity attraction components) associated with the GIA in a $1^{\circ}$ longitude by $1^{\circ}$ latitude grid.

\section{LOW SCENARIO}

The Low Scenario acts as a lower bound and assumes the continuation of the present rate of global mean rise in sea level $\left(\sim 3 \mathrm{~mm} \mathrm{yr}^{-1}\right)$ through 2100 , which is consistent with Sweet et al. (2017). For this scenario, the projections of Slangen et al. (2014), which include contributions from ocean dynamics, steric effects, land-ice mass changes, and groundwater depletion under RCP4.5 from 1986-2005 to 20802099, are scaled down to have a global mean of $0.30 \mathrm{~m}$ (Table 2). The original global mean value is $0.54 \mathrm{~m}$. The correlation coefficient between the observed trends in the past (Han et al., 2015) and the projected trends in the twenty-first century for RCP4.5 at these tide-gauge sites is 0.83 , suggesting that the ad hoc pattern scaling is a reasonable choice for the Low Scenario. Next, the GIA effect from the 


\section{0 / Guoqi Han et al.}

TABLE 1. Locations of tide-gauge stations and nearby GPS stations, as well as the rate of vertical land motion at GPS stations from Sella et al. (2007) and ULR6. Note that data at some stations are unavailable (N/A) in ULR6.

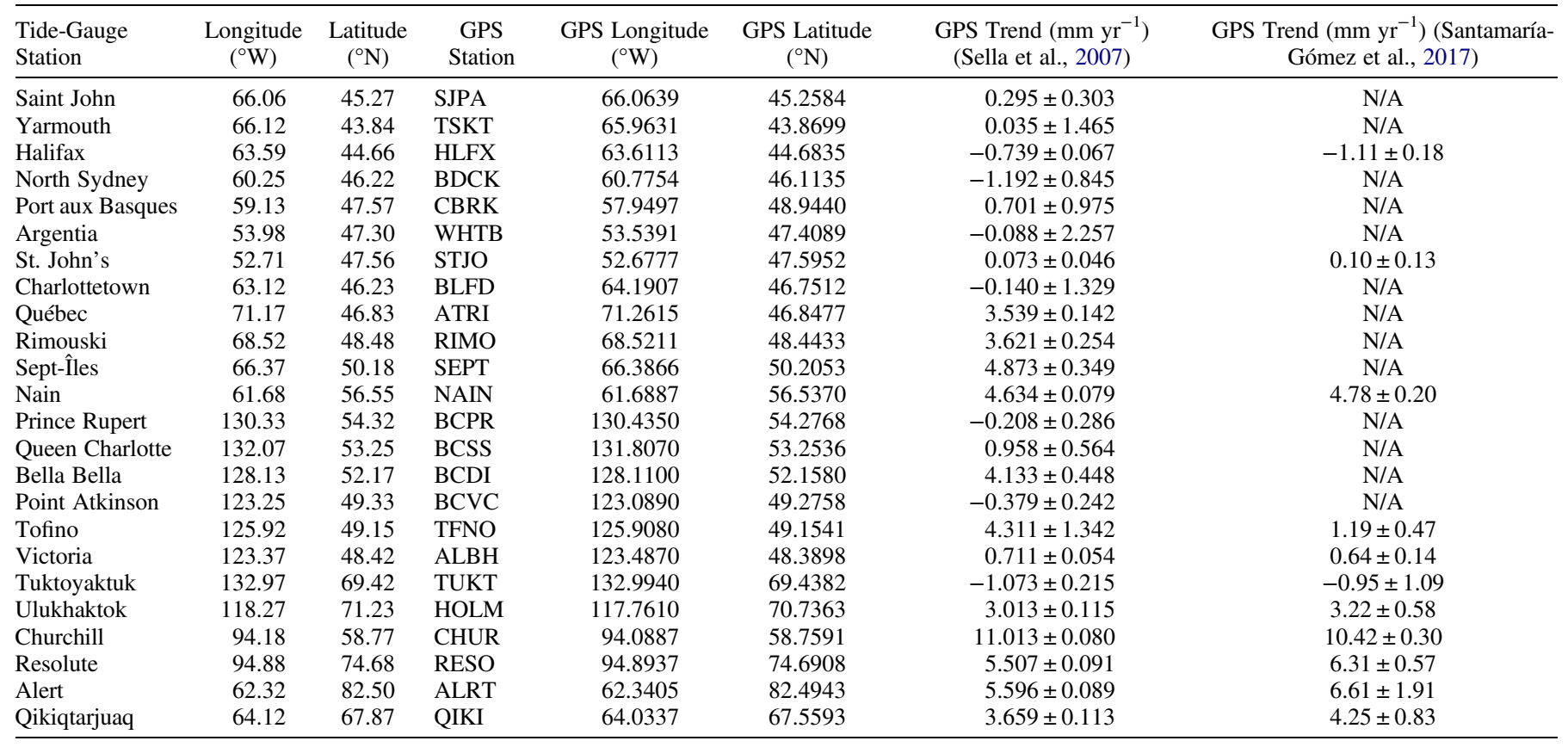

TABLE 2. Summary of global sea level rise $(\mathrm{m})$ under the Low, Intermediate, and High Scenarios during Slangen et al.'s (2014) projection period and the present projection period, respectively.

\begin{tabular}{lccc}
\hline Period & Low & Intermediate & High \\
\hline 1986-2005 to 2080-2099 & 0.30 & 0.71 & 0.83 \\
$2010-2100$ & 0.28 & 0.67 & 0.79 \\
\hline
\end{tabular}

ICE-6G_C model of Stuhne and Peltier (2015) is added. The values of the Low Scenario are calculated following

$$
\begin{aligned}
\Delta \mathrm{RSL}_{L} & =\left(\Delta \mathrm{SL}_{\mathrm{OCEAN} 45}+\Delta \mathrm{SL}_{\mathrm{LICE} 45}+\Delta \mathrm{SL}_{\mathrm{GW}}\right) \\
& (0.3 / 0.54)(90 / 95)+\mathrm{RSL}_{\mathrm{GIA}}(90)+\mathrm{VLMA},
\end{aligned}
$$

where $\Delta \mathrm{RSL}_{L}$ is the RSL change over 2010-2100 (90 years) for the Low Scenario, and $\Delta$ SL OCEAN45 $_{\text {and }} \Delta \mathrm{SL}_{\text {LICE45 }}$ are the regional SLRs of Slangen et al. (2014) under RCP4.5 from 1986-2005 to 2080-2099 (95 years) due to oceanographic and land-ice changes, respectively; $\Delta \mathrm{SL}_{\mathrm{GW}}$ is the regional SLR of Slangen et al. (2014) from 1986-2005 to 2080-2099 due to groundwater depletion. The VLM correction is VLMA, which will be described in Section 2.b. Note that 2010 is the current reference year used by the Canadian Hydrographic Service and linear scaling is assumed to adjust the reference period.

\section{INTERMEDIATE SCENARIO}

For the Intermediate Scenario, we use the climate model results from the RCP8.5 high emission scenario because the projected global mean SLR under the RCP8.5 scenario is consistent with the observed trend for the past twenty-five years
(Nerem et al., 2018). The Intermediate Scenario has a global SLR of $0.71 \mathrm{~m}$ from 1986-2005 to 2080-2099 (Table 2) and is approximately aligned with the Intermediate-Low Scenarios of Parris et al. (2012) and Sweet et al. (2017). The oceanographic component has a global value of $0.28 \mathrm{~m}$. The land-ice component has a global value of $0.35 \mathrm{~m}$, including $0.01 \mathrm{~m}$ from the Antarctic ice sheet $(0.09 \mathrm{~m}$ from dynamics and $-0.08 \mathrm{~m}$ from surface mass balance), $0.12 \mathrm{~m}$ from the Greenland ice sheet $(0.06 \mathrm{~m}$ from both dynamics and surface mass balance), and $0.22 \mathrm{~m}$ from glaciers. The groundwater effect has a global value of $0.08 \mathrm{~m}$. The Intermediate Scenario is computed as follows:

$$
\begin{aligned}
\Delta \mathrm{RSL}_{I}= & \left(\Delta \mathrm{SL}_{\mathrm{OCEAN} 85}+\Delta \mathrm{SL}_{\mathrm{LICE} 85}+\Delta \mathrm{SL}_{\mathrm{GW}}\right)(90 / 95) \\
& +\mathrm{RSL}_{\mathrm{GIA}}(90)+\mathrm{VLMA},
\end{aligned}
$$

where $\Delta \mathrm{RSL}_{I}$ is the RSL change over 2010-2100 for the Intermediate Scenario, $\Delta \mathrm{SL}_{\text {OCEAN85 }}$ and $\Delta \mathrm{SL}_{\mathrm{LICE}}$ 5 are the regional SLR of Slangen et al. (2014) under RCP8.5 from 1986-2005 to 2080-2099 due to oceanographic and land-ice changes, respectively.

\section{HIGH SCENARIO}

The High SLR scenario is designed to consider potential positive feedback effects associated with the Antarctic ice-sheet melt as a result of marine ice-sheet instability (DeConto \& Pollard, 2016; Edwards et al., 2019). The potential effect of the marine ice-cliff instability (MICI) is not considered because Edwards et al. (2019) concluded that previous 


\section{Scenarios of Twenty-First Century Mean Sea Level Rise across Canada / 291}

projections with MICI overestimated SLR this century. Therefore, we will adjust the dynamical component of the Antarctic ice-sheet contribution based on the results of Edwards et al. (2019) without including the MICI parameterization of DeConto and Pollard (2016) but keep the other components unchanged with respect to the Intermediate Scenario. The adjusted Antarctic contribution in the High Scenario has a global mean value of $0.22 \mathrm{~m}$ with a $68 \%$ interval of $[0.13$, $0.32] \mathrm{m}$ over the twenty-first century (100 years) (Edwards et al., 2019) compared with $0.09 \mathrm{~m}$ in the Intermediate Scenario from 1986-2005 to 2080-2099. We determine the additional Antarctic ice-sheet melt contribution for the High Scenario at each station by assuming the same spatial fingerprint for the dynamical component of the Antarctic ice sheet as in the Intermediate Scenario; we first divide the regional value by the global mean $(0.09 \mathrm{~m})$ in the Intermediate Scenario and then multiply by the additional global mean Antarctic dynamic contribution of $0.12 \mathrm{~m}(0.22(95 / 100)-0.09=$ $0.12 \mathrm{~m}$ ). Using the same approach, we determine the standard deviation associated with the additional Antarctic contribution at each station. The High Scenario has a global SLR of $0.83 \mathrm{~m}$ (i.e., $0.71 \mathrm{~m}$ of the Intermediate Scenario plus $0.12 \mathrm{~m}$ of the additional Antarctic ice-sheet melt) from 1986-2005 to 2080-2099 (Table 2) and is approximately aligned with the Intermediate Scenario by Parris et al. (2012) and the Intermediate Scenario by Sweet et al. (2017). The High Scenario is computed as follows:

$$
\begin{aligned}
\Delta \mathrm{RSL}_{H}= & \Delta \mathrm{RSL}_{I}+\Delta \mathrm{SL}_{\mathrm{ADICE} 85}(90 / 95)(0.12 / 0.09) \\
& + \text { VLMA }
\end{aligned}
$$

where $\Delta \mathrm{RSL}_{H}$ is the RSL change over $2010-2100$ for the High Scenario, $\Delta \mathrm{SL}_{\mathrm{ADICE} 85}$ is the regional SLR of Slangen et al. (2014) associated with the dynamical component of the Antarctic ice sheet under RCP8.5 from 1986-2005 to 2080-2099.

\section{b Vertical Land Motion Adjustments}

We use the VLM derived from GPS (an updated dataset of Sella et al. (2007), provided by M. Craymer, personal communication, 2011) to replace the GIA model VLM. We first calculate the VLM difference by subtracting the GPS VLM from the GIA model VLM. The VLM difference is then scaled with time and added to the projected RSL change. It is important to note that the GPS data include the VLM associated with the land-ice melt over the GPS data period, which must be removed from the GPS data when they are used to replace the GIA VLM in the projection. The adjustment procedure can be expressed as follows:

$$
\mathrm{VLMA}=\left(\mathrm{VLM}_{\mathrm{GIA}}-\mathrm{VLM}_{\mathrm{GPS}}+\mathrm{VLM}_{\mathrm{LICE}}+\mathrm{VLM}_{\mathrm{GW}}\right) 90
$$

where VLM $_{\text {GIA }}$ is the rate of VLM from the ICE-6G model;

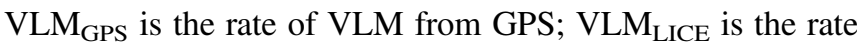
of VLM associated with the present land-ice melt which is the sum of the rates associated with the Greenland ice sheet $\left(\mathrm{VLM}_{\mathrm{GICE}}\right)$, the Antarctic ice sheet $\left(\mathrm{VLM}_{\mathrm{AICE}}\right)$, and glaciers $\left(\mathrm{VLM}_{\mathrm{GLA}}\right) ; \mathrm{VLM}_{\mathrm{GW}}$ is the rate of VLM associated with present groundwater usage. Here we assume that non-climatic VLM rates are continuous over the projection period, which has the caveat of periodic review for updates. We further assume that the $\mathrm{VLM}_{\mathrm{GW}}$ value is negligible for the study region.

We use the vertical velocities obtained from the University of La Rochelle (named ULR6a; Santamaría-Gómez et al., 2017) at 11 GPS stations (Table 1). The GPS time series data cover the period from 1995 to 2014. The time series used had a minimum of three years of data between two consecutive position discontinuities and had data gaps not exceeding $30 \%$ of the total series length. The autocorrelation of the residual series was accounted for in the estimation of the vertical velocity error (Santamaría-Gómez et al., 2017).

We also use the GPS vertical velocity from a Canadian source (Sella et al., 2007) at the remainder of the tide-gauge sites where the ULR6 data are unavailable. The GPS data time series have a duration of about 20 years (from 1993 to 2011). The GPS VLM rates for each location were calculated using a weighted least squares linear fit to daily position estimates (Table 1). Uncertainties were calculated using a velocity error model that accounts for uncorrelated, time-correlated, and random walk noise, as explained in Sella et al. (2007). The vertical velocity from Sella et al. (2007) is generally consistent with that from Santamaría-Gómez et al. (2017) at these 11 stations where data are available from both sources, except at Tofino where the former is overestimated by about $3 \mathrm{~mm} \mathrm{yr}^{-1}$ relative to the latter. Excluding Tofino, the mean difference between the two sources is $0.19 \mathrm{~mm} \mathrm{yr}^{-1}(1.7 \mathrm{~cm}$ over the projection period), with a root-mean-square difference of $0.51 \mathrm{~mm} \mathrm{yr}^{-1}$.

In contrast to the GIA model output that provides a continuous spatial field, GPS locations are discrete. Therefore, we can obtain GIA model values exactly at all tide-gauge stations but need to use nearby GPS values at some tide-gauge stations (Argentia, Charlottetown, North Sydney, and Port aux Basques) where GPS measurements are not available (Table 1). The GPS data include components from GIA, tectonic movement, land-ice melt, groundwater extraction, sediment compaction. The tectonic movement or sediment compaction may occur as sudden vertical offsets that could cause biases in the estimated GPS rates. Such sudden vertical offsets were not noted in Sella et al. (2007). Unlike the GIA VLM, other VLM components contained in GPS data, such as those from tectonic movement along the Pacific coast, may vary significantly during the projection period. Therefore, it is necessary to revise projections when GPS data show significant change in the VLM rate.

In the present study, to account for the effect of land-ice melt on the VLM rate during the GPS data period (assumed to be 1993-2012), we first average Slangen et al.'s (2014) 


\section{2 / Guoqi Han et al.}

model-based global rates for 1993-2012 for the Greenland ice sheet, Antarctic ice sheet, and glaciers. We then calculate the global rates based on the fingerprints of the observational melt of the Greenland and Antarctic ice sheets in 2014 (an update of Shepherd et al. (2012)) and the fingerprint for the observational melt of glaciers averaged over 1900-2013 (Marzeion et al., 2012; updated by Marzeion et al., 2015). Finally, we scale the observational fingerprints using the ratios of the model to observational global rates to obtain the VLM rates during the GPS period. The estimated total VLM rate resulting from land-ice melt during the GPS period is shown in Fig. 2a, with the components of the Greenland ice sheet, Antarctic ice sheet, and glaciers in Figs 2b, 2c, and 2d, respectively. The VLM rate associated with present-day land-ice melt is generally small (below $0.5 \mathrm{~mm} \mathrm{yr}^{-1}$ ) at the Atlantic and Pacific stations and relatively substantial at the eastern Arctic stations, up to $3.8 \mathrm{~mm} \mathrm{yr}^{-1}$ at Alert (Table 3). It is dominated by the contribution from the Greenland ice sheet and glaciers (Fig. 2 and Table 3). Our results are consistent with those of James et al. (2014) at the Atlantic and Arctic stations, except at Alert (their value is $2.1 \mathrm{~mm} \mathrm{yr}^{-1}$ ). At the Pacific stations, our values are generally smaller than those of James et al. $\left(\sim 1 \mathrm{~mm} \mathrm{yr}^{-1}\right)$. Pfeffer et al. (2017) also estimated the VLM rate associated with present-day land-ice melt, and our results are consistent with theirs at stations along the Canadian Atlantic and Arctic coasts but are smaller than their values of 1-2 $\mathrm{mm} \mathrm{yr}^{-1}$ along the Pacific coast.

Figure 3 shows VLMs at the selected tide-gauge sites, including those from GPS data, the GIA model, and land-ice melt, as well as the residuals that are the differences between the GPS values and the sum of the other two components. The residuals could be a result of other processes, such as tectonic movement, groundwater extraction, or sediment compaction, as well as uncertainties associated with the GPS data, GIA model, and land-ice melt component. It is possible that the generally positive residuals are caused by the GIA model overestimating land subsidence along the southeastern Atlantic coast and underestimating land uplift around Hudson Bay. Our residual pattern shows notable differences from that of Pfeffer et al. (2017), with a mean difference of $0.39 \mathrm{~mm} \mathrm{yr}^{-1}$ and a root-mean-square difference of $2.72 \mathrm{~mm} \mathrm{yr}^{-1}$. The discrepancies are mainly related to the VLM difference between Pfeffer et al.'s GIA model and the ICE-6G of Stuhne and Peltier (2015) on the Atlantic and Arctic coasts. On the Pacific coast, the difference in the present-day land-ice component is an important factor.

Our approach for constructing SLR scenarios implicitly assumes that the VLM rate, except that associated with land-
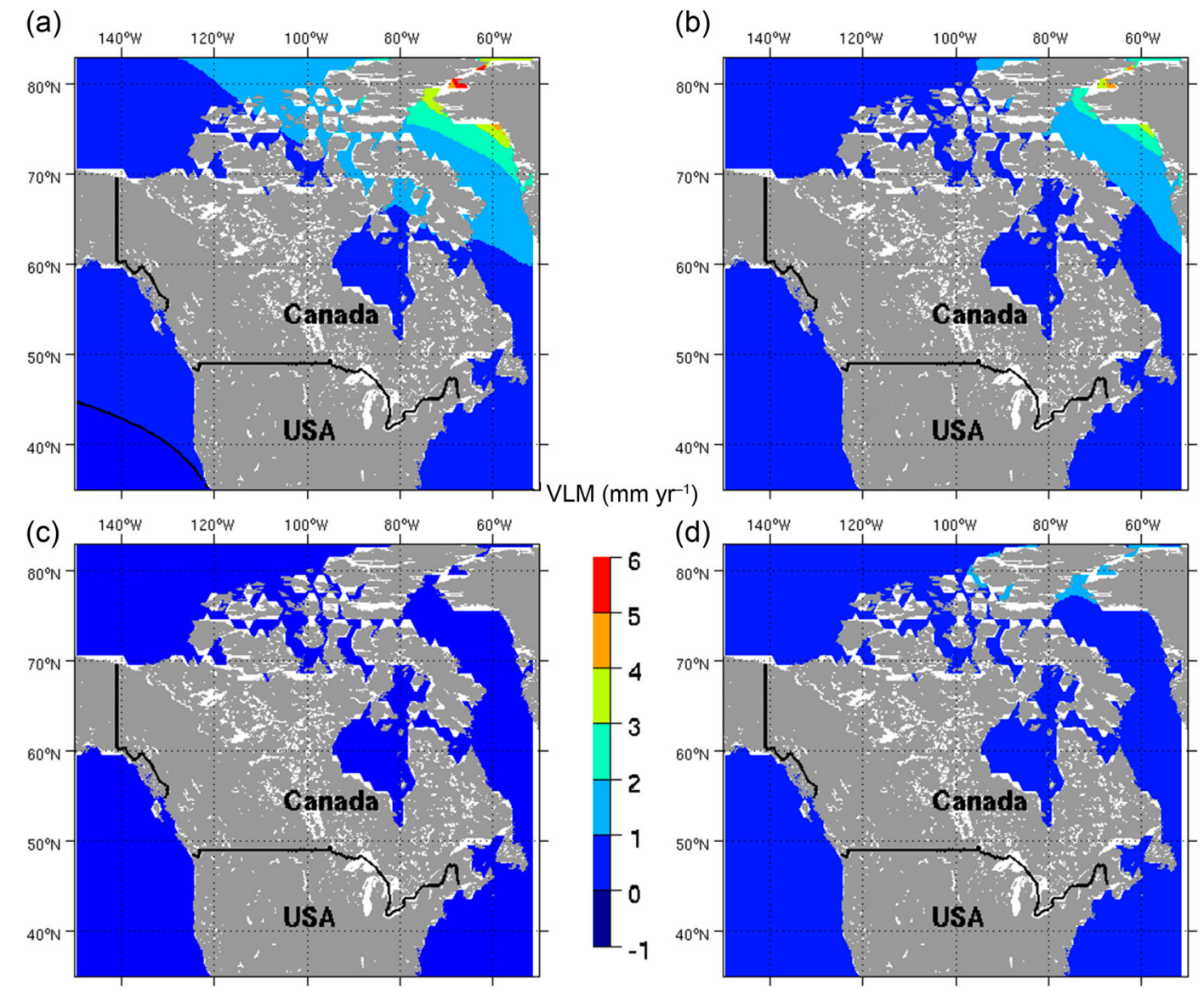

Fig. 2 The VLM rate $\left(\mathrm{mm} \mathrm{yr}^{-1}\right.$ ) associated with present-day land-ice melt: (a) total and contributions by (b) Greenland ice sheet, (c) Antarctic ice sheet, and (d) glaciers. The black line in (a) represents the $0 \mathrm{~mm} \mathrm{yr}^{-1}$ contour. 


\section{Scenarios of Twenty-First Century Mean Sea Level Rise across Canada / 293}

ice melt, is invariable during the projection period and equal to that at present. This assumption may not be appropriate, except for the VLM associated with the GIA process (see further discussion in Section 4).

\section{c Estimating the SLR Uncertainties}

We also provide uncertainties for local SLR projections under the three scenarios. Under the Low and Intermediate Scenarios, the uncertainties are calculated as the root-sum-square of the uncertainties in the ocean, land-ice, and GIA components, as well as the uncertainties in the GPS VLM component. The uncertainties in the ocean and land-ice components represent the root-mean-square spread of projections from process-based models (Slangen et al., 2014). The uncertainties in the GIA component represent the absolute difference between two GIA models: ICE-6G of Stuhne and Peltier (2015) and ICE-5G of Peltier (2004). For the High Scenario, uncertainties in the SLR projections are calculated as the root-sum-square of the uncertainties under the Intermediate Scenario and the uncertainties associated with the additional Antarctic ice-sheet contribution.

\section{Results}

\section{a Low Scenario}

The Low SLR scenario (Section 2.a.1) has a global value of $0.28 \mathrm{~m}$ over 2010-2100 (Table 2) and is adjusted for local VLM (Section 2.b). Over 2010-2100, the mean RSL rise is projected to vary from 0.24 to $0.35 \mathrm{~m}$ at Nova Scotia (North Sydney, Halifax, and Yarmouth), New Brunswick (Saint John), Prince Edward Island (Charlottetown), and Newfoundland (St. John's, Argentia, and Port aux Basques) sites (Fig. 4, Table 4). The highest RSL rise is $0.35 \mathrm{~m}$ at Halifax. Along the northern Gulf of St. Lawrence, the RSL change is smaller, ranging from 0.05 to $0.13 \mathrm{~m}$. At Nain, Labrador, the RSL

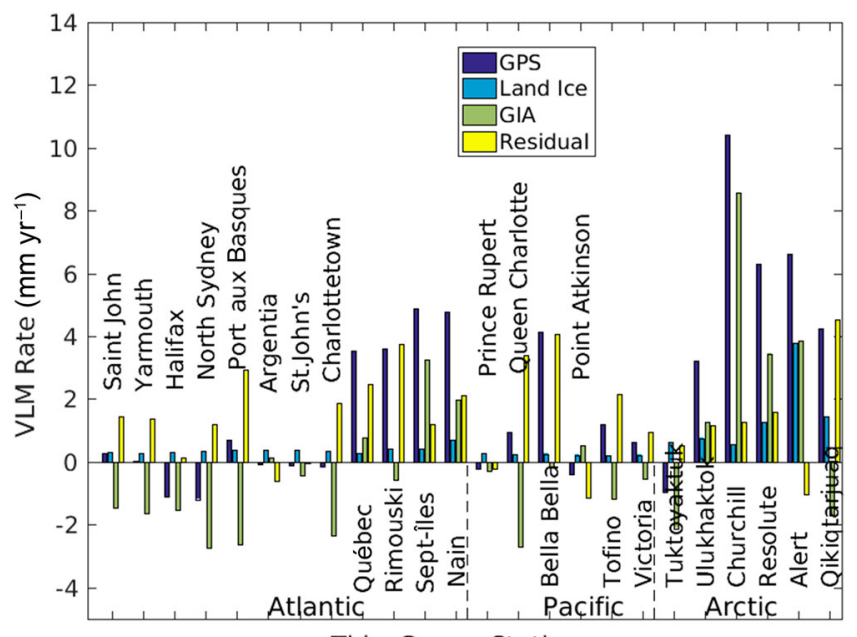

Tide-Gauge Stations

Fig. 3 Components of present-day vertical land motion $\left(\mathrm{mm} \mathrm{yr}^{-1}\right)$. The residual values are calculated by subtracting the sum of the land ice and GIA components from the GPS values. changes little. On the Pacific coast, the RSL change varies from $0.0 \mathrm{~m}$ at Bella Bella to $0.21 \mathrm{~m}$ at Point Atkinson and Prince Rupert. In the Canadian Arctic, the RSL rises by $0.28 \mathrm{~m}$ at Tuktoyaktuk and falls by $0.17 \mathrm{~m}$ at Churchill.

\section{b Intermediate Scenario}

The Intermediate Scenario (Section 2.a.2), adjusted for local VLM (Section 2.b), has a global mean SLR of $0.67 \mathrm{~m}$ for 2010-2100 (Table 2). Over 2010-2100, the local RSL rise varies from $0.61 \mathrm{~m}$ at Port aux Basques to $0.82 \mathrm{~m}$ at Halifax on the southeastern Atlantic Canada coast (Fig. 5, Table 4). The RSL rise is comparatively small along the northeastern Gulf of St. Lawrence and Labrador. On the Pacific coast, the projected RSL rise varies from $0.09 \mathrm{~m}$ at Bella Bella to $0.46 \mathrm{~m}$ at Prince Rupert. Along the Canadian Arctic coast, the RSL is projected to rise to $0.63 \mathrm{~m}$ west of $100^{\circ} \mathrm{W}$ and to fall up to $0.48 \mathrm{~m}$ elsewhere.

\section{c High Scenario}

In the High Scenario (Section 2.a.3), the additional Antarctic contribution of $0.12 \mathrm{~m}$ for the period from 2010 to 2100 raises the total global average sea level by $0.79 \mathrm{~m}$. As a result, to 2100 , local RSL rise is up to $0.96 \mathrm{~m}$ in southeastern Canada (Fig. 6, Table 4). Along the Labrador and northern Gulf of St. Lawrence coasts, the RSL rise will be from $0.24 \mathrm{~m}$ at Nain to $0.55 \mathrm{~m}$ at Québec. On the Pacific coast, the RSL rise will vary from $0.22 \mathrm{~m}$ at Bella Bella to $0.59 \mathrm{~m}$ at Prince Rupert. In the Canadian Arctic, a larger rise of $0.75 \mathrm{~m}$ at Tuktoyaktuk contrasts with a smaller drop in the east.

\section{Discussion}

a Relative Importance of Different Components

For each scenario, a larger RSL rise is projected at tide-gauge stations along the southeastern Atlantic coast, the Pacific coast, and the Beaufort Sea coast than along other Canadian coasts (Fig. 7). For the period from 2010 to 2100, the median RSL rise at tide-gauge stations along the southeastern Atlantic coast could be up to $0.35,0.82$, and $0.96 \mathrm{~m}$ under the Low, Intermediate, and High Scenarios, respectively (Table 4).

The GIA effect is exactly the same for all three scenarios. Some sites, such as Halifax, along the southeastern Atlantic coast have been subsiding due to GIA resulting in a larger RSL rise. In contrast, for the northern coast of the Gulf of St. Lawrence, the coast of Labrador, and the coast of the eastern Canadian Arctic, the land has been rising due to GIA, causing a smaller RSL rise or even a fall. Churchill is located on the western coast of Hudson Bay and is close to the former centre of the Laurentide ice sheet, where the land rise is large and so the RSL fall is large.

For the Intermediate Scenario, the steric and dynamic ocean components are the major contributors to the large RSL rise at tide-gauge stations on the southeast Atlantic coast and at Tuktoyaktuk (Fig. 8). The land-ice melt component contributes 


\section{4 / Guoqi Han et al.}

TABLE 3. Estimates of the rate of vertical land motion at Canadian tide-gauge stations due to present-day melt of the Greenland ice sheet, Antarctic ice sheet, and glaciers.

\begin{tabular}{|c|c|c|c|c|c|c|}
\hline & $\begin{array}{c}\text { Longitude } \\
\left({ }^{\circ} \mathrm{W}\right)\end{array}$ & $\begin{array}{l}\text { Latitude } \\
\left({ }^{\circ} \mathrm{N}\right)\end{array}$ & $\begin{array}{l}\text { Greenland } \\
\left(\mathrm{mm} \mathrm{yr}^{-1}\right)\end{array}$ & $\begin{array}{l}\text { Antarctic } \\
\left(\mathrm{mm} \mathrm{yr}^{-1}\right)\end{array}$ & $\begin{array}{c}\text { Glaciers } \\
\left(\mathrm{mm} \mathrm{yr}^{-1}\right)\end{array}$ & $\begin{array}{c}\text { Total } \\
\left(\mathrm{mm} \mathrm{yr}^{-1}\right)\end{array}$ \\
\hline Saint John & 66.06 & 45.27 & 0.313 & -0.140 & 0.150 & 0.322 \\
\hline Yarmouth & 66.12 & 43.84 & 0.293 & -0.143 & 0.135 & 0.285 \\
\hline Halifax & 63.59 & 44.66 & 0.309 & -0.143 & 0.143 & 0.308 \\
\hline North Sydney & 60.25 & 46.22 & 0.336 & -0.151 & 0.153 & 0.339 \\
\hline Port aux Basques & 59.13 & 47.57 & 0.359 & -0.150 & 0.167 & 0.376 \\
\hline Argentia & 53.98 & 47.30 & 0.365 & -0.152 & 0.164 & 0.377 \\
\hline St. John's & 52.71 & 47.56 & 0.371 & -0.153 & 0.166 & 0.384 \\
\hline Charlottetown & 63.12 & 46.23 & 0.331 & -0.146 & 0.156 & 0.341 \\
\hline Québec & 71.17 & 46.83 & 0.323 & -0.136 & 0.168 & 0.355 \\
\hline Rimouski & 68.52 & 48.48 & 0.353 & -0.137 & 0.185 & 0.401 \\
\hline Sept-Îles & 66.37 & 50.18 & 0.385 & -0.140 & 0.215 & 0.460 \\
\hline Nain & 61.68 & 56.55 & 0.533 & -0.149 & 0.314 & 0.699 \\
\hline Prince Rupert & 130.33 & 54.32 & 0.222 & -0.159 & 0.226 & 0.289 \\
\hline Queen Charlotte & 132.07 & 53.25 & 0.204 & -0.164 & 0.202 & 0.241 \\
\hline Bella Bella & 128.13 & 52.17 & 0.208 & -0.156 & 0.205 & 0.257 \\
\hline Point Atkinson & 123.25 & 49.33 & 0.201 & -0.148 & 0.192 & 0.245 \\
\hline Tofino & 125.92 & 49.15 & 0.186 & -0.155 & 0.174 & 0.204 \\
\hline Victoria & 123.37 & 48.42 & 0.190 & -0.147 & 0.182 & 0.225 \\
\hline Tuktoyaktuk & 132.97 & 69.42 & 0.393 & -0.162 & 0.407 & 0.639 \\
\hline Ulukhaktok & 118.27 & 71.23 & 0.486 & -0.158 & 0.423 & 0.750 \\
\hline Churchill & 94.18 & 58.77 & 0.403 & -0.145 & 0.276 & 0.534 \\
\hline Resolute & 94.88 & 74.68 & 0.763 & -0.161 & 0.697 & 1.299 \\
\hline Alert & 62.32 & 82.50 & 2.636 & -0.159 & 1.304 & 3.781 \\
\hline Qikiqtarjuaq & 64.22 & 67.87 & 0.967 & -0.156 & 0.624 & 1.435 \\
\hline
\end{tabular}

about 0.1 to $0.15 \mathrm{~m}$ at most stations, except -0.1 to $-0.7 \mathrm{~m}$ at sites along the eastern high Arctic where negative land-ice and VLM components cause a much smaller RSL rise or even an RSL fall in spite of large positive steric and ocean dynamic components. The eastern high Arctic is in the near field of the Greenland ice sheet and nearby glaciers' fingerprints. On the Pacific coast, there are significant differences in VLMs at small spatial scales due to tectonic movement (James et al., 2014; Thomson et al., 2008).

For the High Scenario, the contribution of the Antarctic icesheet melt is closer to the oceanographic component at tidegauge stations than for the Intermediate Scenario along Atlantic Canada and comparable to the oceanographic component along Pacific Canada (Fig. 9). This change in the RSL

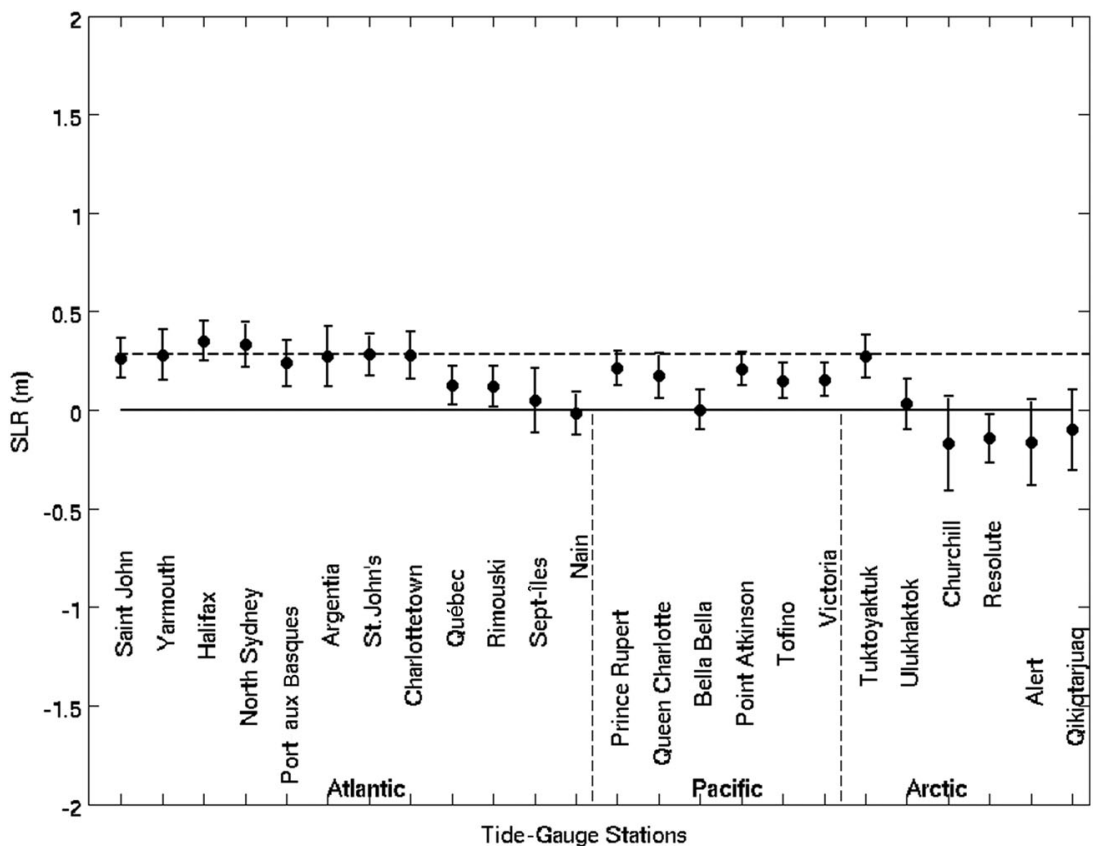

Fig. 4 Local mean RSL projections and their standard errors (m) at selected tide-gauge stations in Canada from 2010 to 2100 under the Low Scenario. The horizontal dashed line depicts the global average. 
Scenarios of Twenty-First Century Mean Sea Level Rise across Canada / 295

TABLE 4. Mean sea level change projections (m) at Canadian tide-gauge stations over 2010-2100. The values from Slangen et al. (2014) and Kopp et al. (2014) include the 5th to 95th percentile ranges. To be consistent with the present projection time period, the values for Slangen et al. (2014) and Kopp et al. (2014) have been linearly scaled by factors of 90/95 and 90/100, respectively. Note that data for some stations are unavailable (N/A) in Kopp et al. (2014).

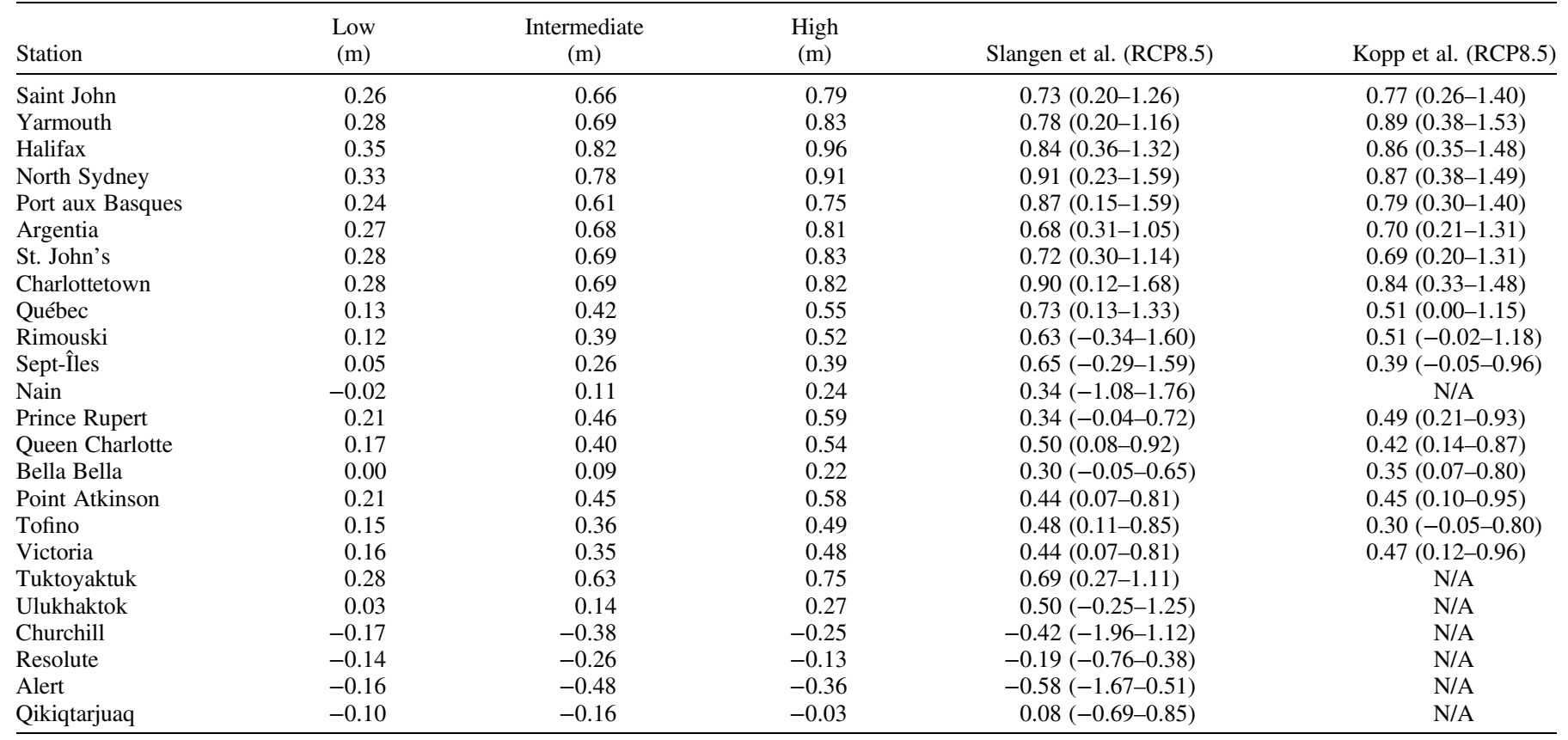

spatial pattern compared with that of the Intermediate Scenario is exclusively a result of the accelerated melt of the Antarctic ice sheet. A characteristic of sea level fingerprints associated with, ice-sheet melt is that in the far field the RSL rise is larger than the global average rise (e.g. Mitrovica et al., 2001, 2009). Canada is in the far field of this melt source; therefore, the accelerated melt of the Antarctic ice sheet causes sea level in Canada to rise more than the global mean. As shown in Fig. 10, the sea-level change caused by the larger contribution of the Antarctic ice sheet varies from about 0.22 to $0.25 \mathrm{~m}$ across Canada, slightly above the global average of $0.20 \mathrm{~m}$.

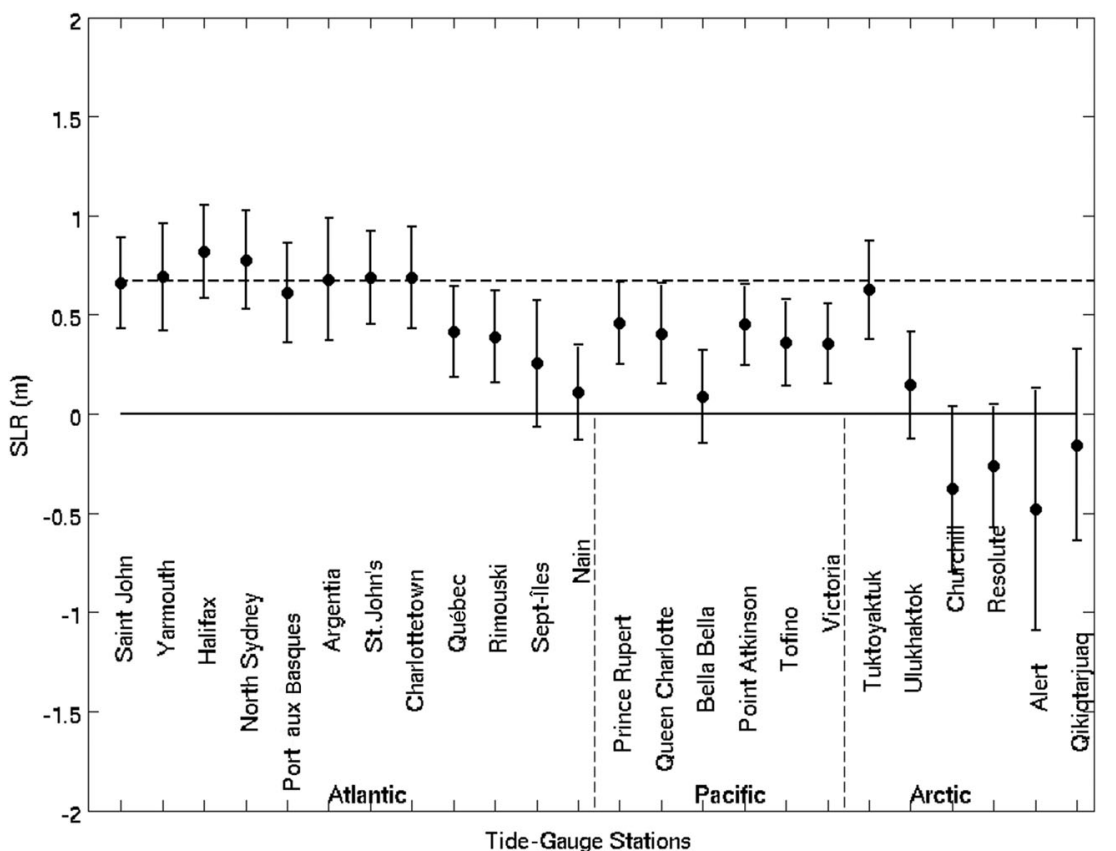

Fig. 5 Local mean RSL projections and their standard deviations (m) at selected tide-gauge sites from 2010 to 2100 under the Intermediate Scenario. The horizontal dashed line depicts the global average. 


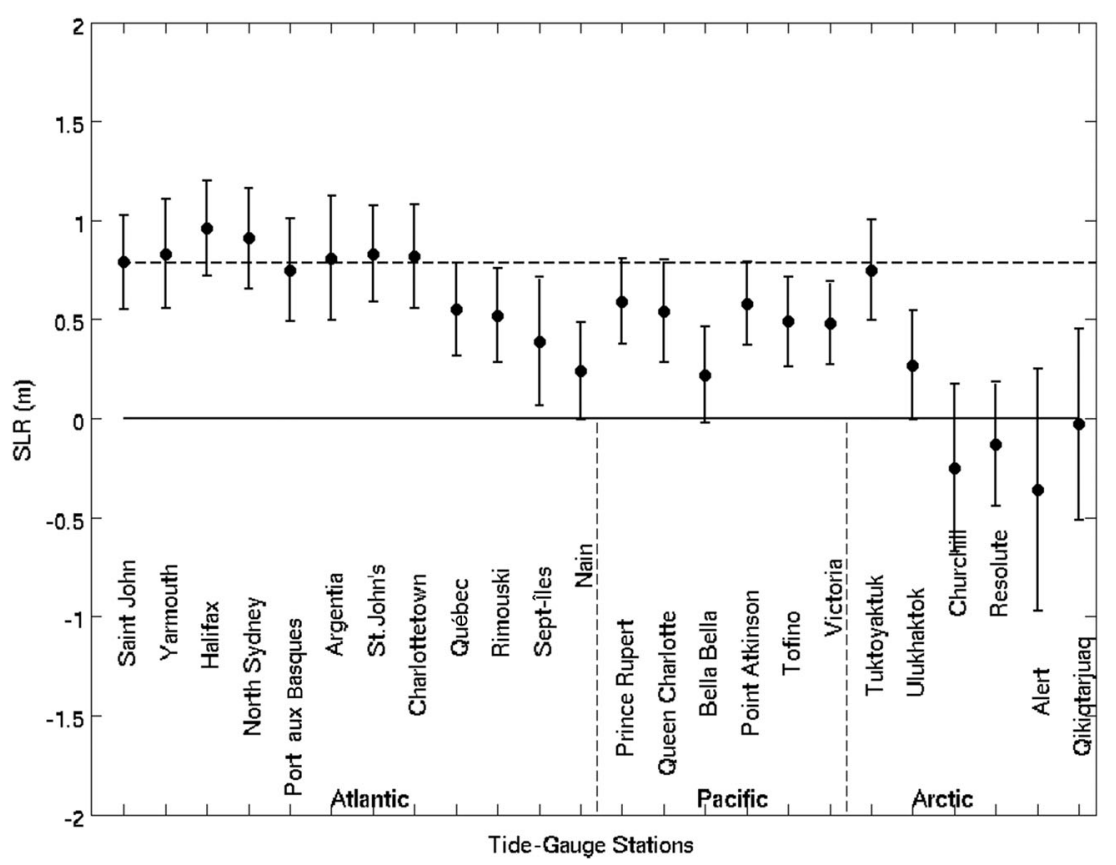

Fig. 6 Local mean RSL projections and their standard deviations (m) at selected tide-gauge stations in Canada from 2010 to 2100 under the High Scenario. The horizontal dashed line depicts the global average.

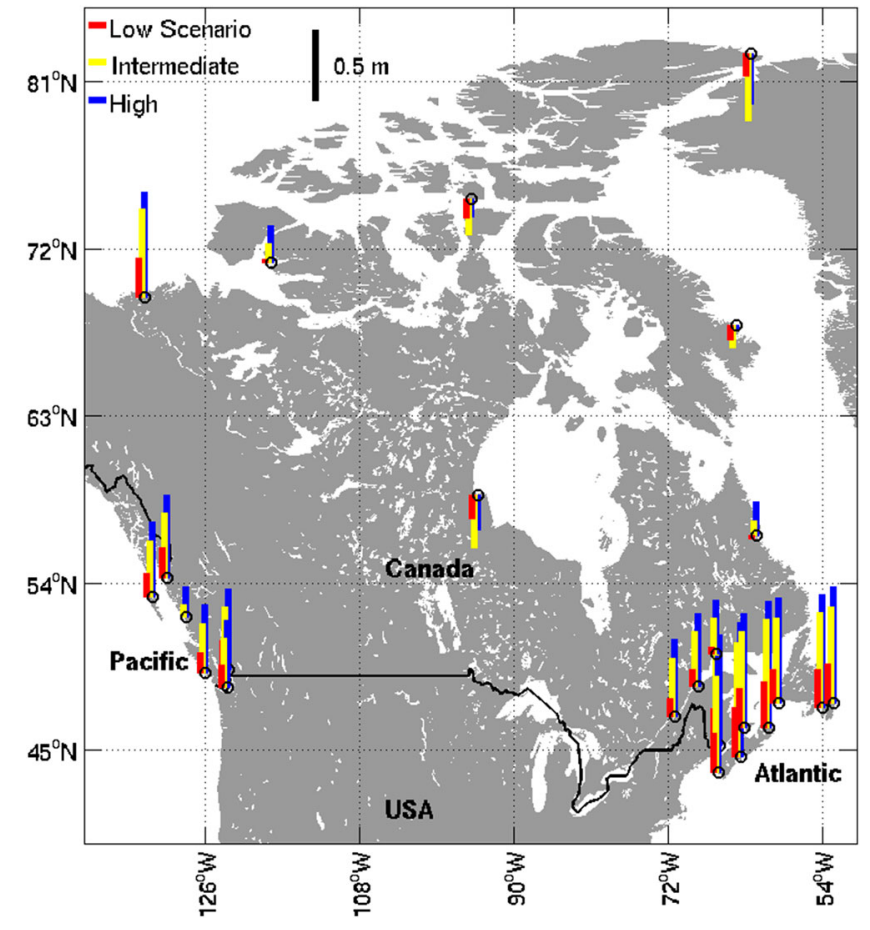

Fig. 7 Geographical illustration of local mean RSL projections (coloured bars) at selected tide-gauge locations (open circles) in Canada from 2010 to 2100 under the three SLR scenarios. The bars are above the tide-gauge location (black rectangles) for rise and below for fall.

\section{b Comparison with Previous Works}

The median values of the Low Scenario are consistent with the 5\% bounds of Kopp et al. (2014), as shown in Table 4. The median values of the Intermediate Scenario along eastern Canada are generally smaller than those of Slangen et al. (2014) under RCP8.5 because of our replacement of the GPS VLM for the GIA model VLM. The differences along western Canada and northern Canada are highly nonuniform, which may be related to the effect of tectonic movement represented in the GPS data. The difference along northern Canada is also highly variable, representing the difference of the GIA effect in the GPS and Peltier's (2004) model VLMs. The median values of the High Scenario are slightly larger (by up to $0.1 \mathrm{~m}$ ) than those of Kopp et al. (2014) at most sites but slightly smaller (by up to $0.13 \mathrm{~m}$ ) at Yarmouth, Port aux Basques, and Bella Bella.

\section{c Plausibility of Scenarios}

The Low Scenario assumes the continuation of the rise in sea level at the present rate over this century. We recognize that the present trend may not represent the future change because a warmer climate will cause more expansion of sea water and additional mass loss of glaciers and ice sheets (Church et al., 2013). Therefore, we treat this Low Scenario as the probable lowest bound.

The Intermediate Scenario is mainly based on state-of-theart climate model output under a high emission scenario. We recognize that climate model projections are subject to large uncertainties. Nevertheless, the climate model projections under RCP8.5 agree with the current climate trajectory. Therefore, the Intermediate Scenario is considered to be the central estimate.

The High Scenario considers possibly accelerated West Antarctic ice sheet (WAIS) melt (e.g., DeConto \& Pollard, 


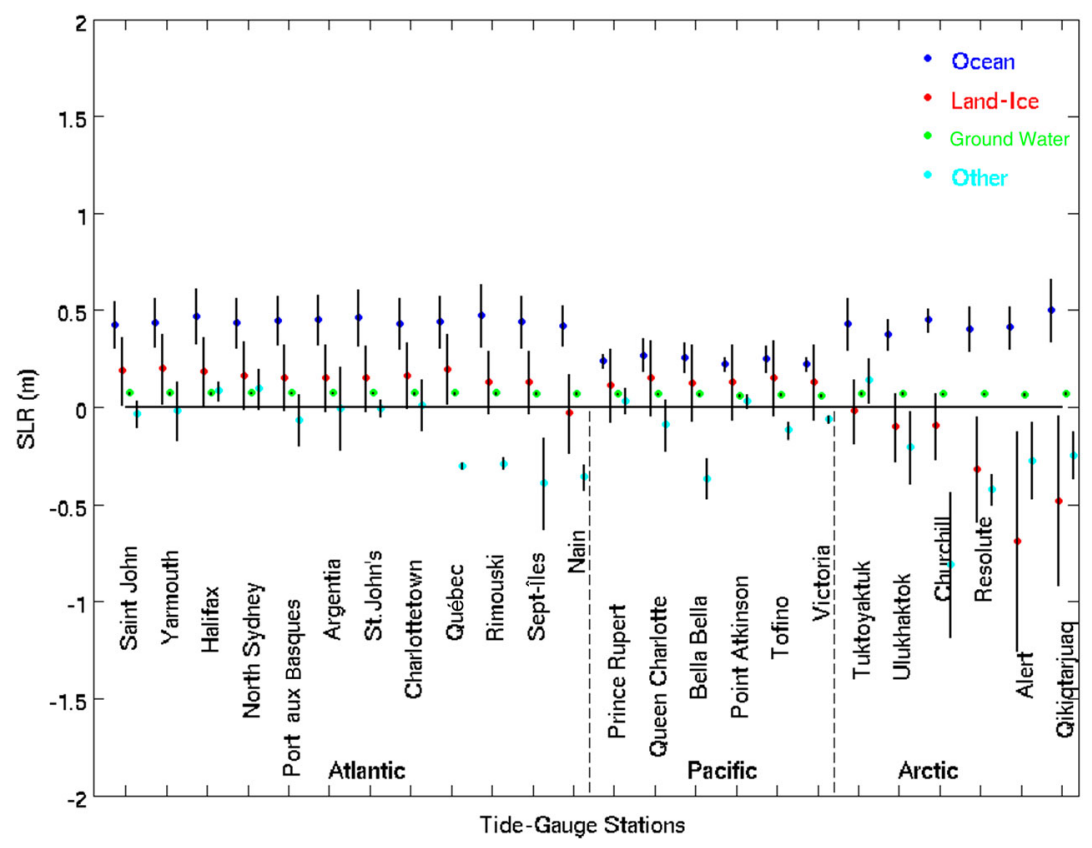

Fig. 8 Components of local mean RSL projections (m) at selected tide-gauge sites from 2010 to 2100 under the Intermediate Scenario.

2016; Edwards et al., 2019) and is, therefore, meant to provide a plausible upper bound. A novel aspect is that through dynamically based spatial scaling, the latest result on global rise in sea level caused by marine ice-sheet instability in Antarctica (Edwards et al., 2019) is incorporated to define a local SLR that provides an upper bound. The WAIS is a marine-based ice sheet, with its bed lying well below sea level and its edges flowing into floating ice shelves. There is evidence of enhanced outflow from the WAIS (Winter et al., 2015). This process has reportedly already begun (Favier et al., 2014). Unlike the Antarctic ice sheet, the Greenland ice sheet has no identified large-scale instabilities.

The High Scenario is not much higher than the Intermediate Scenario and is only slightly higher than the median values of Kopp et al. (2014) (see Section 4.b in our paper). The High Scenario is close to the Intermediate Scenario of Sweet et al. (2017), which has a global mean rise in sea level of $1.0 \mathrm{~m}$ in the twenty-first century. With the Kopp et al. (2014)

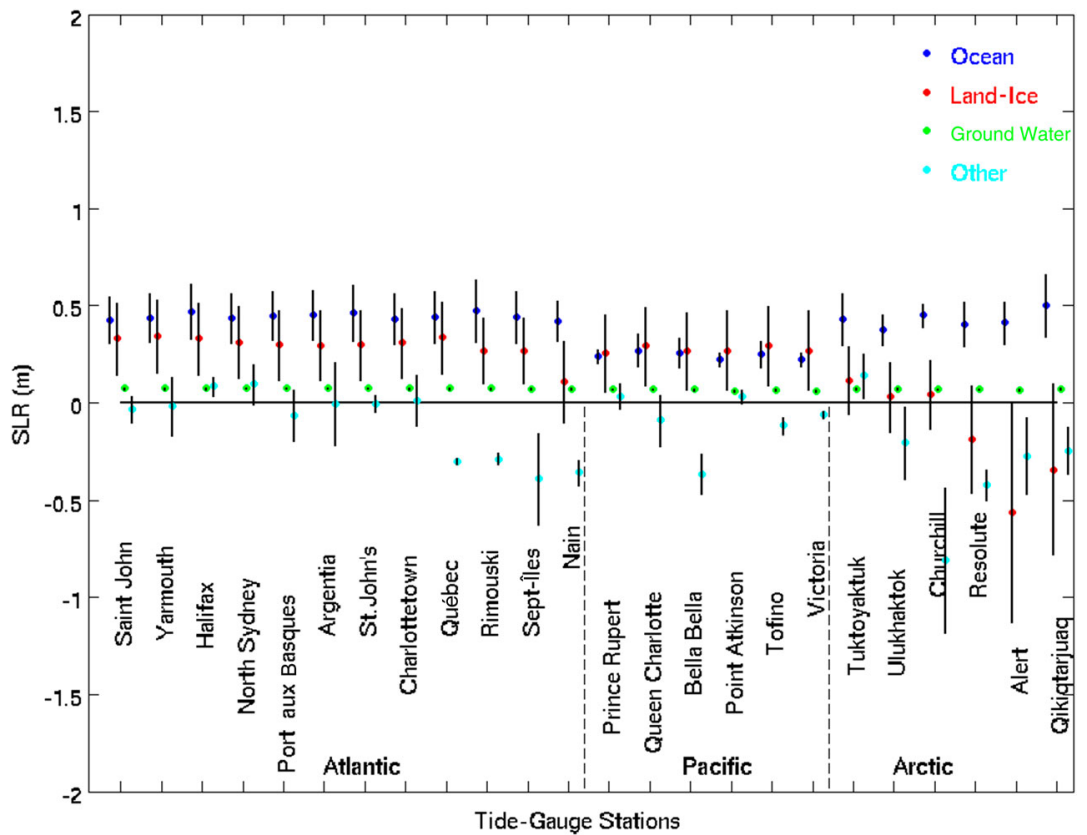

Fig. 9 Components of local mean RSL projections (m) at selected tide-gauge sites from 2010 to 2100 under the High Scenario. 


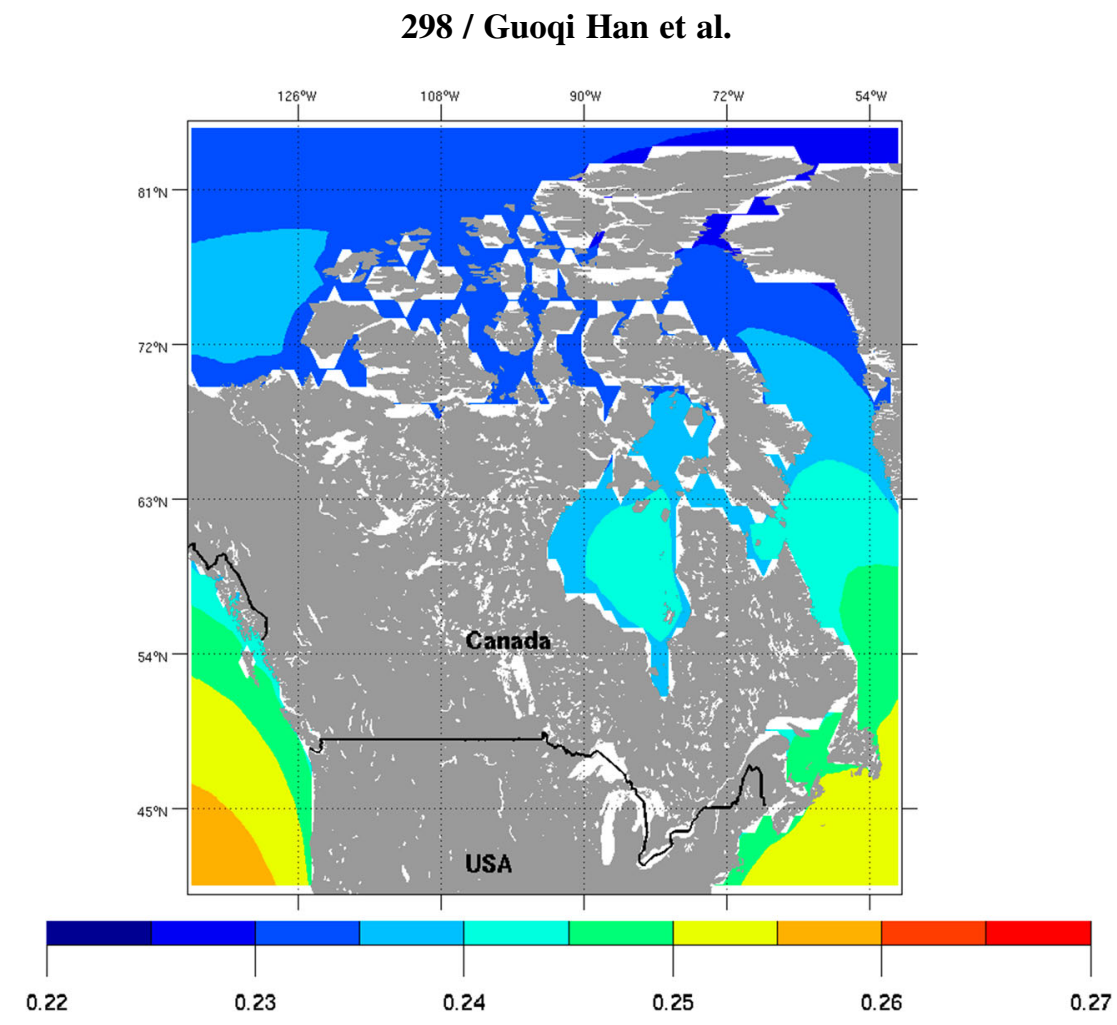

Fig. 10 The contribution of the Antarctic ice sheet from 2010 to 2100 to the projected High Scenario SLR (m) with a global value of $0.2 \mathrm{~m}$.

projections under RCP8.5, the exceedance probability of a $1.0 \mathrm{~m}$ global rise in sea level is $17 \%$ (Sweet et al., 2017) and that of a $2.0 \mathrm{~m}$ rise is $0.3 \%$. The most recent results from Bamber et al. (2019) suggest that an exceedance probability of $2.0 \mathrm{~m}$ in the twenty-first century could be $5 \%$ as a result of increasing contributions from Antarctica. Risk averse decision-makers may want to work with these low risk levels, as appropriate. With a global rise in sea level of $2.0 \mathrm{~m}$, the rise in sea level along southeastern Atlantic Canada will likely exceed $2 \mathrm{~m}$ and be close to $2 \mathrm{~m}$ along the coastlines of the Canadian Pacific, St. Lawrence Estuary, northern Gulf of St. Lawrence, and the western Arctic. The increasing contributions from ice sheets in the past decades are reported in Rignot et al. (2019) and Mouginot et al. (2019). The increasing trends are expected to continue and accelerate during the rest of this century but with large uncertainty.

\section{d Cautions on VLM Adjustments}

A novel aspect in the present approach is the use of GPS observations for estimating VLM. With the present-day land-ice melt effect removed, GPS data provide the most reliable estimates of the present VLM that includes GIA, groundwater extraction, tectonic movements, and sediment compaction. The contribution from present-day land-ice melt varies from 0.02 to $0.34 \mathrm{~m}$ over $2010-2100$. It is small at stations along the Canadian Atlantic coast and the Canadian Pacific coast but is substantial at some stations along the Canadian Arctic. For example, not removing this effect would underestimate SLR over $2010-2100$ by $0.34 \mathrm{~m}$ at Alert.
A key assumption in this study is that VLM has a linear trend. It is reasonable to treat the GIA component as constant over the projection period, but the other components may change substantially. While the eastern coast and the Arctic coast are mainly affected by the GIA process, the Pacific coast is an area with tectonic plate movement and may experience abrupt changes in the VLM rate. This issue can be alleviated by periodically reviewing and updating sea level projections at state level to make use of the best available science (e.g., United Kingdom Climate Projections (Jenkins et al., 2009; Lowe et al., 2018)).

\section{Conclusions}

We have developed three local SLR scenarios at selected tidegauge stations for Canada for the period from 2010 to 2100: Low, Intermediate, and High. According to the definition of these scenarios, results from different sources that account for ocean-atmosphere interaction (from global atmosphereocean general circulation models), GIA effect and non-GIA VLM (from model and GPS observations), and land-ice mass loss (model) are combined to provide projections of RSL change at the selected tide-gauge stations. A novel aspect is that the GPS observations are corrected for the VLM induced by present-day land-ice melt. Not applying this correction would underestimate SLR over 2010-2100 by $0.02-0.34 \mathrm{~m}$ at these tide-gauge stations. Another new aspect is that the latest global SLR associated with marine ice-sheet instability in Antarctica is incorporated in the 


\section{Scenarios of Twenty-First Century Mean Sea Level Rise across Canada / 299}

construction of the High Scenario by dynamically based spatial scaling.

All three scenarios project a larger RSL rise along the southeastern Atlantic coast, the Pacific coast, and the Beaufort Sea coast than along other Canadian coasts in the twenty-first century. Under the Intermediate Scenario, the RSL along the southeastern Atlantic coast is projected to rise by up to $0.82 \mathrm{~m}$ over the period from 2010 to 2100 . In contrast, the RSL is projected to have a lower rise or even fall along the northern coast of the Gulf of St. Lawrence, the coast of Labrador, the coast of Hudson Bay, and the coast of the Eastern Canadian Arctic. Along the Pacific coast, the RSL rise could be up to $0.46 \mathrm{~m}$ at Prince Rupert from 2010 to 2100, with significant differences from station to station at small spatial scales. Under the High Scenario, the RSL rise is projected to vary from $-0.36 \mathrm{~m}$ at Alert on the eastern Canadian Arctic to $0.96 \mathrm{~m}$ at Halifax on the southeastern Atlantic coast from 2010 to 2100.

The availability of local mean SLR scenarios can help government agencies and coastal communities recognize and adapt to sea level changes by 2100 . The High Scenario is for locations where there is a low tolerance for risk (e.g., a power-generating plant cannot tolerate single-event flooding due to a rare extreme event). The Low Scenario is for locations where there is greater tolerance (e.g., a wharf in small craft harbours can tolerate multiple-event flooding). Given the great range of uncertainty in SLR projections, the proposed scenarios will allow coastal engineers and managers to consider multiple future conditions and develop multiple response options. According to the risk tolerance of infrastructure, they will be able to find the most suitable option to mitigate the risk to infrastructure. In practice, these sea level projections need to be combined with extreme event analysis, tidal statistics, and local inundation modelling to inform coastal engineers and managers (e.g., Sweet et al., 2017). It is of great importance for coastal engineers and managers to work with those producing sea level projections to make best use of these projections where possible (e.g., Oppenheimer et al., 2019; The Arlington Group Planning + Architecture Inc., EBA, a Tetra Tech Company, DE Jardine Consulting, and Sustainability Solutions Group, 2013).

\section{Acknowledgements}

We thank Paul Curran, Blair Greenan, Richard Thomson, Li Zhai, and Tomas James for their advice through the Aquatic Climate Change and Adaptation Services Program (ACCASP) project, as well as Michael Craymer for providing GPS data. Constructive comments and suggestions were received from the two anonymous reviewers.

\section{Disclosure statement}

No potential conflict of interest was reported by the author(s).

\section{Funding}

The work is part of a project funded by the ACCASP of Fisheries and Oceans Canada.

\section{References}

Aarup, T., Church, J. A., Wilson, W. S., \& Woodworth, P. L. (Eds.). (2010). Sea-level rise and variability - a summary for policy makers (IOC/BRO/ 2010/5). ICO/UNESCO. https://www.preventionweb.net/files/15422 189369e1.pdf

The Arlington Group Planning + Architecture Inc., EBA, a Tetra Tech Company, DE Jardine Consulting, and Sustainability Solutions Group. (2013). Sea level rise adaptation primer. British Columbia Ministry of Environment. https://www2.gov.bc.ca/assets/gov/environment/climatechange/adaptation/resources/slr-primer.pdf

Bamber, J. L., Oppenheimer, M., Kopp, R., Aspinall, W. P., \& Cooke, R. M. (2019). Ice sheet contributions to future sea-level rise from structured expert judgment. Proceedings of the National Academy of Sciences, 116(23), 11195-11200. https://doi.org/10.1073/pnas.1817205116

Carton, J. A., \& Giese, B. S. (2008). A reanalysis of ocean climate using Simple Ocean Data Assimilation (SODA). Monthly Weather Review, 136 (8), 2999-3017. https://doi.org/10.1175/2007MWR1978.1

Church, J. A., Clark, P. U., Cazenave, A., Gregory, J. M., Jevrejeva, S., Levermann, A., Merrifield, M. A., Milne, G. A., Nerem, R. S., Nunn, P. D., Payne, A. J., Pfeffer, W. T., Stammer, D., \& Unnikrishnan, A. S. (2013). Sea level change. In T. F. Stocker, D. Qin, G.-K. Plattner, M. Tignor, S. K. Allen, J. Boschung, A. Nauels, Y. Xia, V. Bex, \& P. M. Midgley (Eds.), Climate change 2013: The physical science basis. Contribution of Working Group I to the Fifth Assessment Report of the Intergovernmental Panel on Climate Change (pp. 1173-1216). Cambridge University Press.

DeConto, R. M., \& Pollard, D. (2016). Contribution of Antarctica to past and future sea-level rise. Nature, 531(7596), 591-597. https://doi.org/10.1038/ nature 17145
Edwards, T. L., Brandon, M. A., Durand, G., Edwards, N. R., Golledge, N. R., Holden, P. B., Nias, I. J., Payne, A. J., Ritz, C., \& Wernecke, A. (2019). Revisiting Antarctic ice loss due to marine ice-cliff instability. Nature, 566(7742), 58-64. https://doi.org/10.1038/s41586-0190901-4

Favier, L., Durand, G., Cornford, S. L., Gudmundsson, G. H., Gagliardini, O., Gillet-Chaulet, F., Zwinger, T., Payne, A. J., \& Le Brocq, A. M. (2014) Retreat of Pine Island Glacier controlled by marine ice-sheet instability. Nature Climate Change, 4(2), 117-121. https://doi.org/10.1038/ nclimate2094

Garner, A. J., Weiss, J. L., Parris, A., Kopp, R. E., Horton, R. M., Overpeck, J. T., \& Horton, B. P. (2018). Evolution of 21 st century sea level rise projections. Earth's Future, 6(11), 1603-1615. https://doi.org/10.1029/ 2018EF000991

Han, G., Ma, Z., Bao, H., \& Slangen, A. (2014). Regional differences of relative sea level changes in the Northwest Atlantic: Historical trends and future projections. Journal of Geophysical Research: Oceans, 119(1), 156-164. https://doi.org/10.1002/2013JC009454

Han, G., Ma, Z., Chen, N., Thomson, R., \& Slangen, A. (2015). Changes of mean relative sea level around Canada in the twentieth and twenty-first centuries. Atmosphere-Ocean, 53(5), 452-463. https://doi.org/10.1080/ 07055900.2015.1057100

Hinkel, J., Jaeger, C., Nicholls, R. J., Lowe, J., Renn, O., \& Shi, P. (2015). Sea-level rise scenarios and coastal risk management. Nature Climate Change, 5(3), 188-190. https://doi.org/10.1038/nclimate2505

Jackson, L. P., \& Jevrejeva, S. (2016). A probabilistic approach to 21st century regional sea-level projections using RCP and high-end scenarios. Global 


\section{0 / Guoqi Han et al.}

and Planetary Change, 146, 179-189. https://doi.org/10.1016/j.gloplacha. 2016.10.006

James, T. S., Henton, J. A., Leonard, L. J., Darlington, A., Forbes, D. L., \& Craymer, M. (2014). Relative sea-level projections in Canada and the adjacent mainland United States (Open File 7737). Geological Survey of Canada, https://doi.org/10.4095/295574

Jenkins, G. J., Murphy, J. M., Sexton, D. S., Lowe, J. A., Jones, P., \& Kilsby, C. G. (2009). UK climate projections: Briefing report. Met Office Hadley Centre. Exeter. http://cedadocs.ceda.ac.uk/id/eprint/1321

Jevrejeva, S., Moore, J. C., \& Grinstede, A. (2012). Sea level projections to $\mathrm{AD} 2500$ with a new generation of climate change scenarios. Global and Planetary Change, 80-81, 14-20. https://doi.org/10.1016/j.gloplacha. 2011.09.006

Kopp, R. E., DeConto, R. M., Bader, D. A., Hay, C. C., Horton, R. M., Kulp, S., Oppenheimer, M., Pollard, D., \& Strauss, B. H. (2017). Evolving understanding of Antarctic ice-sheet physics and ambiguity in probabilistic sealevel projections. Earth's Future, 5(12), 1217-1233. https://doi.org/10. 1002/2017EF000663

Kopp, R. E., Horton, R. M., Little, C. M., Mitrovica, J. X., Oppenheimer, M., Rasmussen, D. J., Strauss, B. H., \& Tebaldi, C. (2014). Probabilistic 21st and 22nd century sea-level projections at a global network of tide-gauge sites. Earth's Future, 2(8), 383-406. https://doi.org/10.1002/ 2014EF000239

Le Cozannet, G., Manceau, J.-C., \& Rohmer, J. (2017). Bounding probabilistic sea-level projections within the framework of the possibility theory. Environmental Research Letters, 12(1), 014012. https://doi.org/10.1088/ 1748-9326/aa5528

Lowe, J. A., Bernie, D., Bett, P., Bricheno, L., Brown, S., Calvert, D., Clark, R., Eagle, K., Edwards, T., Fosser, G., Fung, F., Gohar, L., Good, P., Gregory, J., Harris, G., Howard, T., Kaye, N., Kendon, E., Krijnen, J., ... Belecher, S. (2018). UKCP18 science overview. Met Office Hadley centre. https://www.metoffice.gov.uk/pub/data/weather/uk/ukcp18/sciencereports/UKCP18-Overview-report.pdf

Marzeion, B., Jarosch, A. H., \& Hofer, M. (2012). Past and future sea-level change from the surface mass balance of glaciers. The Cryosphere, 6(6), 1295-1322. https://doi.org/10.5194/tc-6-1295-2012

Marzeion, B., Leclercq, P. W., Cogley, J. G., \& Jarosch, A. H. (2015). Global reconstructions of glacier mass change during the 20th century are consistent. The Cryosphere, 9(6), 2399-2404. https://doi.org/10.5194/tc-9-23992015

Mazzotti, S., Jones, C., \& Thomson, R. E. (2008). Relative and absolute sea level rise in western Canada and northwestern United States from a combined tide gauge-GPS analysis. Journal of Geophysical Research, 113 (C11), C11019. https://doi.org/10.1029/2008JC004835

Mengel, M., Levermann, A., Frieler, K., Robinson, A., Marzeion, B., \& Winkelmann, R. (2016). Future sea level rise constrained by observations and long-term commitment. Proceedings of the National Academy of Sciences, 113(10), 2597-2602. https://doi.org/10.1073/pnas.1500515113

Mitrovica, J. X., Gomez, N., \& Clark, P. U. (2009). The sea-level fingerprint of West Antarctic collapse. Science, 323(5915), 75. https://doi.org/10.1126/ science. 1166510

Mitrovica, J. X., Tamisiea, M. E., Davis, J. L., \& Milne, G. A. (2001). Recent mass balance of polar ice sheets inferred from patterns of global sea-level change. Nature, 409(6823), 1026-1029. https://doi.org/10.1038/35059054

Moss, R. H., Edmonds, J. A., Hibbard, K. A., Manning, M. R., Rose, S. K., van Vuuren, D. P., Carter, T. R., Emori, S., Kainuma, M., Kram, T., Meehl, G. A., Mitchell, J. F., Nakicenovic, N., Riahi, K., Smith, S. J., Stouffer, R. J., Thomson, A. M., Weyant, J. P., \& Wilbanks, T. J. (2010). The next generation of scenarios for climate change research and assessment. Nature, 463(7282), 747-756. https://doi.org/10.1038/nature08823

Mouginot, J., Rignot, E., Bjørk, A. A., van den Broekee, M., Millana, R., Morlighema, M., Noele, B., Scheuchla, B., \& Wood, M. (2019). Fortysix years of Greenland Ice sheet mass balance from 1972 to 2018. Proceedings of the National Academy of Sciences, 116(19), 9239-9244. https://doi.org/10.1073/pnas.1904242116

Muis, S., Verlaan, M., Nicholls, R. J., Brown, S., Hinkel, J., Lincke, D., Vafeidis, A. T., Scussolini, P., Winsemius, H. C., \& Ward, P. J. (2017).
A comparison of two global datasets of extreme sea levels and resulting flood exposure. Earth's Future, 5(4), 379-392. https://doi.org/10.1002/ 2016EF000430

Nerem, R. S., Beckley, B. D., Fasullo, J. T., Hamlington, B. D., Masters, D., \& Mitchum, G. T. (2018). Climate-change-driven accelerated sea-level rise detected in the altimeter era. Proceedings of the National Academy of Sciences, 115(9), 2022-2025. https://doi.org/10.1073/pnas.1717312115

Oppenheimer, M., Glavovic, B. C., Hinkel, J., van de Wal, R., Magnan, A. K., Abd-Elgawad, A., Cai, R., Cifuentes-Jara, M., DeConto, R. M., Ghosh, T., Hay, J., Isla, F., Marzeion, B., Meyssignac, B., \& Sebesvari, Z. (2019). Sea level rise and implications for low-lying islands, coasts and communities. In H.-O. Pörtner, D. C. Roberts, V. Masson-Delmotte, P. Zhai, M. Tignor, E. Poloczanska, K. Mintenbeck, A. Alegría, M. Nicolai, A. Okem, J. Petzold, B. Rama, \& N. M. Weyer (Eds.), IPCC special report on the ocean and cryosphere in a changing climate (pp. 321-445). IPCC.

Palmer, M. D., Harris, G. R., \& Gregory, J. M. (2018). Extending CMIP5 projections of global mean temperature change and sea level rise due to thermal expansion using a physically-based emulator. Environmental Research Letters, 13(8), 084003. https://doi.org/10.1088/1748-9326/aad2e4

Parris, A., Bromirski, P., Burkett, V., Cayan, D., Culver, M., Hall, J., Horton, R., Knuuti, K., Moss, R., Obeysekera, J., Sallenger, A., \& Weiss, J. (2012). Global sea level rise scenarios for the US National Climate Assessment (NOAA Tech Memo OAR CPO-1). https://scenarios.globalchange.gov/ sites/default/files/NOAA_SLR_r3_0.pdf

Peltier, W. (2004). Global glacial isostasy and the surface of the ice-age earth: The ICE-5G (VM2) model and GRACE. Annual Review of Earth and Planetary Sciences, 32(1), 111-149. https://doi.org/10.1146/annurev. earth.32.082503.144359

Pfeffer, J., Spada, G., Mémin, A., Boy, J.-P., \& Allemand, P. (2017). Decoding the origins of vertical land motions observed today at coasts. Geophysical Journal International, 210(1), 148-165. https://doi.org/10 1093/gji/ggx142

Rahmstorf, S., Foster, G., \& Cazenave, A. (2012). Comparing climate projections to observations up to 2011. Environmental Research Letters, 7(4), 044035. https://doi.org/10.1088/1748-9326/7/4/044035

Ranger, N., Reeder, T., \& Lowe, J. (2013). Addressing ‘deep' uncertainty over long-term climate in major infrastructure projects: Four innovations of the Thames Estuary 2100 project. EURO Journal on Decision Processes, 1 (3-4), 233-262. https://doi.org/10.1007/s40070-013-0014-5

Rignot, E., Mouginot, J., Scheuchla, B., van den Broeked, M., van Wessem, M. J., \& Morlighema, M. (2019). Four decades of Antarctic ice sheet mass balance from 1979-2017. Proceedings of the National Academy of Sciences, 116(4), 1095-1103. https://doi.org/10.1073/pnas.1812883116

Santamaría-Gómez, A., Gravelle, M., Dangendorf, S., Marcos, M., Spada, G., \& Wöppelmann, G. (2017). Uncertainty of the 20th century sea-level rise due to vertical land motion errors. Earth and Planetary Science Letters, 473, 24-32. https://doi.org/10.1016/j.eps1.2017.05.038

Sella, G. F., Stein, S., Dixon, T. H., Craymer, M., James, T. S., Mazzotti, S., \& Dokka, R. K. (2007). Observation of glacial isostatic adjustment in "stable" North America with GPS. Geophysical Research Letters, 34(2), L02306. https://doi.org/10.1029/2006GL027081

Shepherd, A., Ivins, E. R., Geruo, A., Barletta, V. R., Bentley, M. J., Bettadpur, S., Briggs, K. H., Bromwich, D. H., Forsberg, R., Galin, N., Horwath, M., Jacobs, S., Joughin, I., King, M. A., Lenaerts, J. T. M., Li, J., Ligtenberg, S. R. M., Luckman, A., Luthcke, S. B., ... Zwally, H. J. (2012). A reconciled estimate of ice-sheet mass balance. Science, 338 (6111), 1183-1189. https://doi.org/10.1126/science.1228102

Slangen, A. B. A., Carson, M., Katsman, C. A., van de Wal, R. S. W., Kohl, A., Vermeersen, L. L. A., \& Stammer, D. (2014). Projecting twenty-first century regional sea-level changes. Climatic Change, 124(1-2), 317-332. https://doi.org/10.1007/s10584-014-1080-9

Stuhne, G. R., \& Peltier, W. R. (2015). Reconciling the ICE-6G_C reconstruction of glacial chronology with ice sheet dynamics: The cases of Greenland and Antarctica. Journal of Geophysical Research: Earth Surface, 120(9), 1841-1865. https://doi.org/10.1002/2015JF003580

Sweet, W. V., Kopp, R. E., Weaver, C. P., Obeysekera, J., Horton, R. M., Robert Thieler, E., \& Zervas, C. (2017). Global and regional sea level 
Scenarios of Twenty-First Century Mean Sea Level Rise across Canada / 301

rise scenarios for the United States (NOAA Technical Report NOS COOPS 083). https://tidesandcurrents.noaa.gov/publications/techrpt83_ Global_and_Regional_SLR_Scenarios_for_the_US_final.pdf

Thomson, R. E., Bornhold, B. D., \& Mazzotti, S. (2008). An examination of the factors affecting relative and absolute sea level in coastal British Columbia (Canadian Technical Report of Hydrography and Ocean Sciences 260), Fisheries and Oceans Canada, Ottawa.

van der Pol, T. D., \& Hinkel, J. (2019). Uncertainty representations of mean sea-level change: A telephone game? Climatic Change, 152(3-4), 393411. https://doi.org/10.1007/s10584-018-2359-z
Wahl, T., Haigh, I. D., Nicholls, R., Arns, A., Dangendorf, S., Hinkel, J., \& Slangen, A. B. A. (2017). Understanding extreme sea levels for broadscale coastal impact and adaptation analysis. Nature Communications, 8 (1), 16075. https://doi.org/10.1038/ncomms 16075

Winter, K., Woodward, J., Ross, N., Dunning, S. A., Bingham, R. G., Corr, H. F. J., \& Siegert, M. J. (2015). Airborne radar evidence for tributary flow switching in Institute Ice Stream, West Antarctica: Implications for ice sheet configuration and dynamics. Journal of Geophysical Research: Earth Surface, 120(9), 1611-1625. https://doi.org/10.1002/ 2015JF003518 